\title{
UPAYA MENINGKATKAN KEMAMPUAN SISWA MENULIS TEKS PROSEDUR MELALUI MODEL PEMBELAJARAN CHAIN WRITING DI SMP
}

\author{
Rusino \\ Guru Bahasa Inggris SMP Negeri 5 Kubu Kabupaten Kubu Raya \\ Email :senomulyo3@gmail.com
}

\begin{abstract}
This classroom action research was conducted in Class IX A SMP Negeri 5 Kubu with a total of 22 students. The objectives to be achieved in this study are to improve students' ability to compile procedural texts, develop effective, efficient and fun learning strategies and learning models, students can actively involve themselves in communication activities by expressing their ideas, opinions and feelings simply both verbally. or written. The technique used in this research is to make observations / observations and give student performance tests in the form of written tests. Then the next goal of Classroom Action Research is to find out to what extent learning through the Chain writing learning model can improve student learning outcomes in writing procedural texts in class IX A at SMP Negeri $5 \mathrm{Kubu}$. Classroom action research (CAR) was conducted in 2 cycles, from the results of the actions taken were proven to improve student learning outcomes in English lessons by reaching the KKM standard, namely 70 . From $64.31 \%$ in cycle I, it could increase to $78.63 \%$. in cycle 2. The results of this action research indicate that the chain writing learning model is effective in improving students' skills in writing procedural texts.
\end{abstract}

Keywords: Chain Writing, Learning Model, Student ability, Procedure Text, Writing

\section{PENDAHULUAN}

Bahasa sebagai alat komunikasi memiliki peran sentral dalam meningkatkan perkembangan intelektual, sosial, dan emosional siswa dan diharapkan mampu menunjang keberhasilan dalam mempelajari semua bidang. Pembelajaran bahasa diharapkan membantu Siswa mengenal dirinya, budayanya, budaya orang lain, mengemukakan gagasan dan perasaan, berpartisipasi dalam masyarakat yang menggunakan bahasa tersebut, dan menemukan serta menggunakan kemampuan analitis dan imaginatif yang ada dalam dirinya. Oleh sebab itu pembelajaran bahasa terutama bahasa Inggris sebagai bahasa kedua hendaknya mengajarkan keempat kemampuan yang harus dimiliki oleh siswa.

Pembelajaran Bahasa Inggris diarahkan untuk meningkatkan kemampuan Siswa untuk berkomunikasi dengan baik dan benar, baik secara lisan maupun tulis. Belajar tidak hanya sekedar menghafal, siswa harus mengkonstruksi pengetahuan dibenak mereka sendiri. Siswa belajar mengalami, mencatat sendiri pola pola bermakna dari pengetahuan baru dan bukan diberi begitu saja oleh guru

Proses belajar mengajar merupakan kegiatan utama sekolah. Dalam proses ini siswa membangun makna dan pemahaman dengan bimbimgan guru. Kegiatan belajar mengajar hendaknya memberikan kesempatan kepada siswa untuk melakukan hal hal secara lancar dan termotivasi. Suasana belajar yang diciptakan guru harus melibatkan siswa secara aktif. Di sekolah terutama guru diberikan kebebasan untuk mengelola kelas yang meliputi strategi, pendekatan, metode dan teknik pembelajaran yang efektif, disesuaikan dengan karakteristik materi, siswa, guru dan sumber daya yang tersedia di sekolah.

Pada kenyataannya di sekolah untuk bisa mengajarkan keempat kemampuan secara seimbang bukanlah cara yang mudah, terutama dalam mengajar kemampuan menulis (Writing), kemampuan yang satu ini sering sulit untuk diajarkan. Hal ini disebabkan kemampuan menulis menghendaki penguasaan berbagai unsur kebahasaan dan unsur diluar bahasa itu sendiri yang akan menjadi isi tulisan. Baik unsur bahasa maupun unsur isi haruslah terjalin sedemikian rupa sehingga menghasilkan tulisan yang runtut dan padu. Agar dapat mengajarkan pembelajaran dengan baik diperlukan suatu kejelian dari pengajar untuk dapat memilih dan menggunakan strategi maupun metode pembelajaran.

Penguasaan kemampuan Bahasa Inggris (language skill) merupakan sebuah syarat mutlak yang harus dimiliki diera komunikasi dan globalisasi saat ini. Pembelajaran Bahasa Inggris (Language Learning) di jenjang SMP merupakan materi pokok sebagai bagian dari fungsi pengembangan diri siswa dalam bidang Ilmu Pengetahuan, teknologi dan seni yang diharapkan setelah menamatkan studi, Mereka mampu tumbuh dan berkembang menjadi individu yang cerdas, terampil dan berkepribadian sebagai bekal hidup di masa mendatang.

Penguasan materi pelajaran Bahasa Inggris dalam jenjang SMP meliputi empat keterampilan berbahasa, yaitu: menyimak, berbicara, membaca dan menulis. Semua itu didukung oleh unsur-unsur bahasa lainnya, yaitu: Kosa Kata, Tata Bahasa dan Pronunciation sesuai dengan tema sebagai alat pencapai tujuan. Dari ke empat keterampilan berbahasa di atas, Writing (menulis) merupakan salah satu kemampuan berbahasa yang dirasa sering menjadi masalah bagi siswa dalam proses pembelajaran Bahasa Inggris. Hal tersebut sangat menarik untuk diteliti mengingat kemampuan menulis (writing ability) sangatlah dipengaruhi oleh penguasaan kosa kata, struktur bahasa dan kemampuan siswa dalam merangkai kata menjadi sebuah teks yang berterima. Perbedaan secara grammatikal antara bahasa Inggris sebagai bahasa 
asing dan bahasa Indonesia sebagai bahasa utama merupakan masalah yang sering timbul pada saat belajar menulis. Kemampuan mengungkapkan makna dalam langkah retorika dalam essai pendek sederhana dengan menggunakan ragam bahasa tulis secara akurat, lancar dan berterima untuk berinteraksi dalam konteks kehidupan sehari-hari dalam teks Prosedur adalah salah satu Kompetensi Dasar (KD) yang harus dikuasai oleh siswa Kelas IX Sekolah Menengah Pertama (SMP).

Teks prosedur adalah jenis teks yang berisi cara-cara untuk membuat atau melakukan suatu hal, yang dijelaskan menurut metode langkah per langkah secara runtut dan detail. Tujuan teks prosedur adalah memberi informasi terkait masalah tertentu.

Adanya teks prosedur cukup penting untuk memberi informasi dan penjelasan mengenai langkah-langkah melakukan sesuatu. Dalam sebuah produk, teks prosedur juga berperan penting untuk menjelaskan penggunaan produk tersebut bagi konsumen.

Secara umum teks prosedur dibagi menjadi 3 jenis, yakni teks prosedur sederhana, teks prosedur kompleks, dan teks prosedur protokol. Teks prosedur sederhana tidak membutuhkan banyak langkah, sementara teks prosedur kompleks membutuhkan banyak langkah dan waktu. Adapun teks prosedur protokol tidak terlalu rumit dan mudah dipahami.

Contoh teks prosedur misalnya menjelaskan cara membuat kopi, cara membuat nasi goreng, cara mendaftar ke universitas, cara menggunakan DVD player, cara mengedit video dengan baik, cara membuat laporan hasil penelitian, dan sebagainya.

Pengertian teks prosedur menurut Ismail Masya (1994:45) adalah teks yang menjelskan rangkaian tugas-tugas yang saling berhubungan yang merupakan urutan-urutan menurut waktu dan tata cara tertentu untuk melaksanakan suatu pekerjaan yang dilaksanakan berulang-ulang. Sedangkan definisi teks prosedur menurut pendapat dari Muhammad Ali (2000:23) merupakan sebuah teks yang menjelaskan tata cara kerja atau cara menjalankan suatu pekerjaan tertentu. Kemudian menurut Ida Nuraida (2008:54), arti teks prosedur adalah teks yang menjelaskan urutan langkahlangkah dimana pekerjaan tersebut dilakukan, berhubungan dengan apa yang dilakukan, bagaimana melakukannya, bilamana melakukannya, di mana melakukannya, dan siapa yang melakukannya. Terakhir Menurut Mulyadi (2001:56), pengertian teks prosedur adalah teks yang menjelaskan urutan kegiatan klerikal, biasanya melibatkan beberapa orang dalam satu departemen atau lebih, yang dibuat untuk menjamin penanganan secara seragam transaksi perusahaan yang terjadi berulang-ulang.

Tujuan orang menulis adalah untuk menjelaskan dan melaporkan responnya atas suatu pengalaman yang menarik, menyenangkan atau menyedihkan dalam hidup ini (Barnet, 1979: 27). Sesuatu pengalaman yang menarik, menyenangkan ataupun menyedihkan itu bisa sesuatu yang bisa dilihat, didengar, dirasakan, maupun dalam bentuk yang lain. Berangkat dari pemikiran inilah, memperdengarkan karangan atau menayangkan cerita pengalaman adalah merupakan sumber pembelajaran menulis yang sangat efektif.
Peneliti menawarkan suatu metode pembelajaran yang bisa dipakai sebagai alternatif dalam pembelajaran menulis (Writing). Metode ini dinamakan Chain Writing, metode ini sangat effektif untuk menumbuhkan kebiasaan menulis bagi Siswa.Chain Writing adalah menulis bahasa Inggris secara berantai dengan cara merangkai kalimat dari siswa satu dilanjutkan oleh siswa lainnya secara berurutan (Cohen 1994:34). Chain Writing bisa diterima sebagai metode dalam mencapai peningkatan tujuan pembelajaran. Cara seperti ini menghasilkan pemerolehan belajar, pengembangan daya pikir yang lebih tinggi, perkembangan perilaku sosial, cara mengadakan interaksi dan merupakan sebuah cara untuk mengatur keheterogenan akademis dalam kelas.

Chain Writing adalah dikerjakan dalam kelompok-kelompok yang akan memberikan kesempatan istimewa pada siswa-siswi untuk aktif menulis. Menurut Bianco (2002:33), Chain writing adalah merupakan teknik yang direkomendasikan dalam rekonstruksi sekolah. Teknik kelompok ini juga secara luas direkomendasikan sebagai cara memperoleh derajat rasa persamaan dalam kelas, ini disampaikan oleh Mackenzie, N., \& Veresov, N. (2013:54). Manfaat dari Chain Writing yang dilaksanakan secara berkelompok ini adalah tersedianya peningkatan kesempatan komunikasi yang besar sesama siswa, pendapat ini menurut Hornby (2015:69)

Shelley Stagg Peterson (2016:76) menyimpulkan bahwa belajar secara berkelompok lebih efektif dari cara atau teknik yang lain. Berdasarkan latar belakang dan rumusan masalah yang telas dikemukakan diatas, maka hipotesis yang peneliti ajukan sebagai berikut: model pembelajaran chain writing dapat meningkatkan kemampuan siswa dalam menulis teks prosedur di kelas IX A di SMP Negeri 5 Kubu tahun pelajaran 2019/2020

\section{METODE PENELITIAN}

Dalam penelitian ini subyek yang melaksanakan tindakan adalah Peneliti sebagai guru bahasa inggris dan subyek yang menerima tindakan adalah siswa kelas IX A SMP Negeri 5 Kubu sebanyak 22 siswa.Dalam pelaksanaan tindakan, rancangan dilakukan dalam 2 siklus yang meliputi ; (a) perencanaan, (2) tindakan, (3) pengamatan, (4) refleksi. Pelaksanaan tindakan dalam penelitian inidilakukan dalam2 siklus. Waktu yang digunakan setiap kali pertemuan adalah 2 x 40 menit. Siklus pertama dilaksanakan pada tanggal 9 sampai dengan 16 September 2019 dan siklus kedua pada tanggal 23 sampai dengan 30 Oktober 2019.

Penelitian ini dilaksanakan sesuai dengan prosedur rencana pembelajaran dan skenario pembelajaran. Dalam pengumpulan data teknik yang digunakan adalah menggunakan observasi dan tes. Indikator keberhasilan dalam penelitian ini adalah apabila Siswa di kelas IX A SMP Negeri 5 Kubu mendapatkan nilai sesuai dengan nilai standar KKM yaitu 70 . Penilaian dilakukan baik ketika proses penyusunan maupun hasil yang telah diselesaikan oleh siswa.

\section{HASIL DAN PEMBAHASAN PENELITIAN Hasil Siklus 1}

Peneliti mempersiapkan perangkat pembelajaran yang terdiri dari rencana pelajaran 1, buku teks, soal tes formatif 1 dan alat-alat 
pengajaran yang mendukung. Selain itu juga dipersiapkan lembar observasi pengolaan pembelajaran. Pelaksanaan kegiatan belajar mengajar untuk siklus 1 dilaksanakan pada tanggal 9 September sampai dengan 16 September 2019 dengan jumlah Siswa 22 orang. Dalam hal ini peneliti bertindak sebagai guru. Adapun proses belajar mengajar mengacu pada rencana pelajaran yang telah dipersiapkan. Pengamatan (observasi) dilaksanakan bersamaan dengan pelaksaaan belajar mengajar. Pada akhir proses belajar mengajar Siswa diberi tes formatif 1 dengan tujuan untuk mengetahui tingkat keberhasilan Siswa dalam proses belajar mengajar yang telah dilakukan.Adapun data hasil penelitian pada siklus 1 adalah seperti pada tabel berikut :

Tabel 1. Distribusi Hasil Tes pada Siklus 1

\begin{tabular}{|c|c|c|c|c|c|}
\hline \multirow{2}{*}{ No } & \multirow{2}{*}{ Nama Siswa } & \multirow{2}{*}{$\mathbf{L} / \mathbf{P}$} & \multirow{2}{*}{ Skor } & \multicolumn{2}{|c|}{ Keterangan } \\
\hline & & & & Tuntas & Tidak Tuntas \\
\hline 1 & $\mathrm{AO}$ & $\mathrm{L}$ & 70 & $\sqrt{ }$ & \\
\hline 2 & AR & $\mathrm{L}$ & 70 & $\sqrt{ }$ & \\
\hline 3 & AS & $\mathrm{L}$ & 60 & & $\sqrt{ }$ \\
\hline 4 & AA & $\mathrm{P}$ & 60 & & $\sqrt{ }$ \\
\hline 5 & $\mathrm{AL}$ & $\mathrm{L}$ & 65 & & $\sqrt{ }$ \\
\hline 6 & $\mathrm{AK}$ & $\mathrm{P}$ & 60 & & $\sqrt{ }$ \\
\hline 7 & $\mathrm{CN}$ & $\mathrm{L}$ & 60 & & $\sqrt{ }$ \\
\hline 8 & DG & $\mathrm{L}$ & 75 & $\sqrt{ }$ & \\
\hline 9 & $\mathrm{DN}$ & $\mathrm{P}$ & 60 & & $\sqrt{ }$ \\
\hline 10 & DA & $\mathrm{P}$ & 70 & $\sqrt{ }$ & \\
\hline 11 & ES & $\mathrm{P}$ & 70 & $\sqrt{ }$ & \\
\hline 12 & $\mathrm{MC}$ & $\mathrm{L}$ & 60 & & $\sqrt{ }$ \\
\hline 13 & $\mathrm{NH}$ & $\mathrm{P}$ & 60 & & $\sqrt{ }$ \\
\hline 14 & NQ & $\mathrm{P}$ & 65 & & $\sqrt{ }$ \\
\hline 15 & NLA & $\mathrm{P}$ & 60 & & $\sqrt{ }$ \\
\hline 16 & $\mathrm{RE}$ & $\mathrm{L}$ & 60 & & $\sqrt{ }$ \\
\hline 17 & RM & $\mathrm{P}$ & 75 & $\sqrt{ }$ & \\
\hline 18 & $\mathrm{RH}$ & $\mathrm{P}$ & 60 & & $\sqrt{ }$ \\
\hline 19 & RT & $\mathrm{P}$ & 60 & & $\sqrt{ }$ \\
\hline 20 & SA & $\mathrm{P}$ & 75 & $\sqrt{ }$ & \\
\hline 21 & SN & $\mathrm{P}$ & 60 & & $\sqrt{ }$ \\
\hline 22 & YS & $\mathrm{L}$ & 60 & & $\sqrt{ }$ \\
\hline \multicolumn{2}{|c|}{ Jumlah Total } & 22 & 1415 & - & - \\
\hline \multicolumn{2}{|c|}{ Skor Maksimum Individu } & - & 100 & - & - \\
\hline \multicolumn{2}{|c|}{ Skor Maksimum Kelas } & - & 2200 & - & - \\
\hline
\end{tabular}

Penerapan model pembelajaran chain writing diperoleh persentase nilai ketuntasan belajar Siswa untuk pelajaran Bahasa Inggris adalah $64,31 \%$ atau ada 8 Siswa dari 22 Siswa sudah tuntas belajar. Hasil tersebut menunjukkan bahwa pada siklus pertama secara klasikal Siswa belum tuntas belajar, karena ketuntasan yang dikehendaki yaitu 70 sesuai nilai KKM. Hal ini disebabkan karena siswa masih merasa baru dan belum mengerti apa yang dimaksudkan dan digunakan guru dengan menggunakan model pembelajaran chain writing. Dalam pelaksanaan kegiatan belajar mengajar diperoleh informasi dari hasil pengamatan bahwa siswa kurang begitu antusias selama pembelajaran berlangsung.

\section{Siklus 2}

Pelaksanaan kegiatan belajar mengajar untuk siklus 2 dilaksanakan pada tanggal 23 Oktober sampai dengan 30 Oktober 2019 di SMP Negeri 5 Kubu tahun pelajaran 2019-2020. Adapun proses belajar mengajar mengacu pada rencana pelajaran dengan memperhatikan revisi pada siklus 1, sehingga kesalahan atau kekurangan pada siklus 1 tidak terulang lagi pada siklus 2. Pengamatan (observasi) dilaksanakan bersamaan dengan pelaksanaan belajar mengajar.

Pada akhir proses belajar mengajar Siswa diberi tes formatif 2 dengan tujuan untuk mengetahui tingkat keberhasilan Siswa. Instrumen yang digunakan adalah tes formatif 2. Adapun data hasil penelitian pada siklus 2 adalah sebagai berikut;

Tabel 2. Distribusi Hasil Tes Pada Siklus 2

\begin{tabular}{|c|c|c|c|c|c|}
\hline \multirow[b]{2}{*}{ No } & \multirow[b]{2}{*}{ Nama Siswa } & \multirow[b]{2}{*}{$\mathbf{L} / \mathbf{P}$} & \multirow[b]{2}{*}{ Skor } & \multicolumn{2}{|c|}{ Keterangan } \\
\hline & & & & Tuntas & Tidak Tuntas \\
\hline 1 & $\mathrm{AO}$ & $\mathrm{L}$ & 90 & $\sqrt{ }$ & \\
\hline 2 & AR & $\mathrm{L}$ & 85 & $\sqrt{ }$ & \\
\hline 3 & $\mathrm{AS}$ & $\mathrm{L}$ & 70 & $\sqrt{ }$ & \\
\hline 4 & AA & $\mathrm{P}$ & 70 & $\sqrt{ }$ & \\
\hline 5 & $\mathrm{AL}$ & $\mathrm{L}$ & 75 & $\sqrt{ }$ & \\
\hline 6 & $\mathrm{AK}$ & $\mathrm{P}$ & 75 & $\sqrt{ }$ & \\
\hline 7 & $\mathrm{CN}$ & $\mathrm{L}$ & 70 & $\sqrt{ }$ & \\
\hline 8 & DG & $\mathrm{L}$ & 90 & $\sqrt{ }$ & \\
\hline 9 & DN & $\mathrm{P}$ & 80 & $\sqrt{ }$ & \\
\hline
\end{tabular}




\begin{tabular}{|c|c|c|c|c|c|}
\hline 10 & DA & $\mathrm{P}$ & 90 & $\sqrt{ }$ & \\
\hline 11 & ES & $\mathrm{P}$ & 85 & $\sqrt{ }$ & \\
\hline 12 & $\mathrm{MC}$ & $\mathrm{L}$ & 70 & $\sqrt{ }$ & \\
\hline 13 & $\mathrm{NH}$ & $\mathrm{P}$ & 70 & $\sqrt{ }$ & \\
\hline 14 & NQ & $\mathrm{P}$ & 75 & $\sqrt{ }$ & \\
\hline 15 & NLA & $\mathrm{P}$ & 75 & $\sqrt{ }$ & \\
\hline 16 & $\mathrm{RE}$ & $\mathrm{L}$ & 70 & $\sqrt{ }$ & \\
\hline 17 & $\mathrm{RM}$ & $\mathrm{P}$ & 90 & $\sqrt{ }$ & \\
\hline 18 & RH & $\mathrm{P}$ & 80 & $\sqrt{ }$ & \\
\hline 19 & RT & $\mathrm{P}$ & 70 & $\sqrt{ }$ & \\
\hline 20 & $\mathrm{SA}$ & $\mathrm{P}$ & 90 & $\sqrt{ }$ & \\
\hline 21 & $\mathrm{SN}$ & $\mathrm{P}$ & 80 & $\sqrt{ }$ & \\
\hline 22 & YS & $\mathrm{L}$ & 80 & $\sqrt{ }$ & \\
\hline \multicolumn{2}{|c|}{ Jumlah Total } & 22 & 1730 & - & - \\
\hline \multicolumn{2}{|c|}{ Skor Maksimum Individu } & - & 100 & - & - \\
\hline \multicolumn{2}{|c|}{ Skor Maksimum Kelas } & - & 2200 & - & - \\
\hline
\end{tabular}

Berdasarkan tabel di atas diperoleh persentase nilai tes formatif pelajaran Bahasa Inggris sebesar $78,63 \%$, ketuntasan belajar yang telah tercapai yaitu 70, sesuai nilai KKM. Hasil pada siklus 2 ini mengalami peningkatan lebih baik dari siklus 1 . Adanya peningkatan hasil belajar pada siklus 2 ini dipengaruhi oleh adanya peningkatan kemampuan guru dalam menerapkan model pembelajaran chain writing, sehingga siswa menjadi lebih terbiasa dengan pembelajaran seperti ini sehingga siswa lebih mudah dalam memahami materi yang telah diberikan. Disamping itu, ketuntasan ini juga dipengaruhi oleh kerja sama dari Siswa yang telah menguasai materi pelajaran untuk mengajari temannya yang belum menguasai.
Pada siklus 2 guru telah menerapkan model pembelajaran chain writing dengan baik, dan dilihat dari aktivitas Siswa serta hasil belajar Siswa pelaksanaan proses belajar mengajar sudah berjalan dengan baik. Maka tidak diperlukan revisi terlalu banyak, tetapi yang perlu diperhatikan untuk tindakah selanjutnya adalah memaksimalkan dan mempertahankan apa yang telah ada dengan tujuan agar pada pelaksanaan proses belajar mengajar selanjutnya penerapan model pembelajaran chain writing, dapat meningkatkan proses belajar mengajar sehingga tujuan pembelajaran dapat tercapai. Setelah dilakukan tindakan pada siklus 1 dan siklus 2 menunjukkan hasil sebagai berikut :

Tabel 3. Analisis Hasil Tes denganMenggunakan Model Pembelajaran Chain Writing

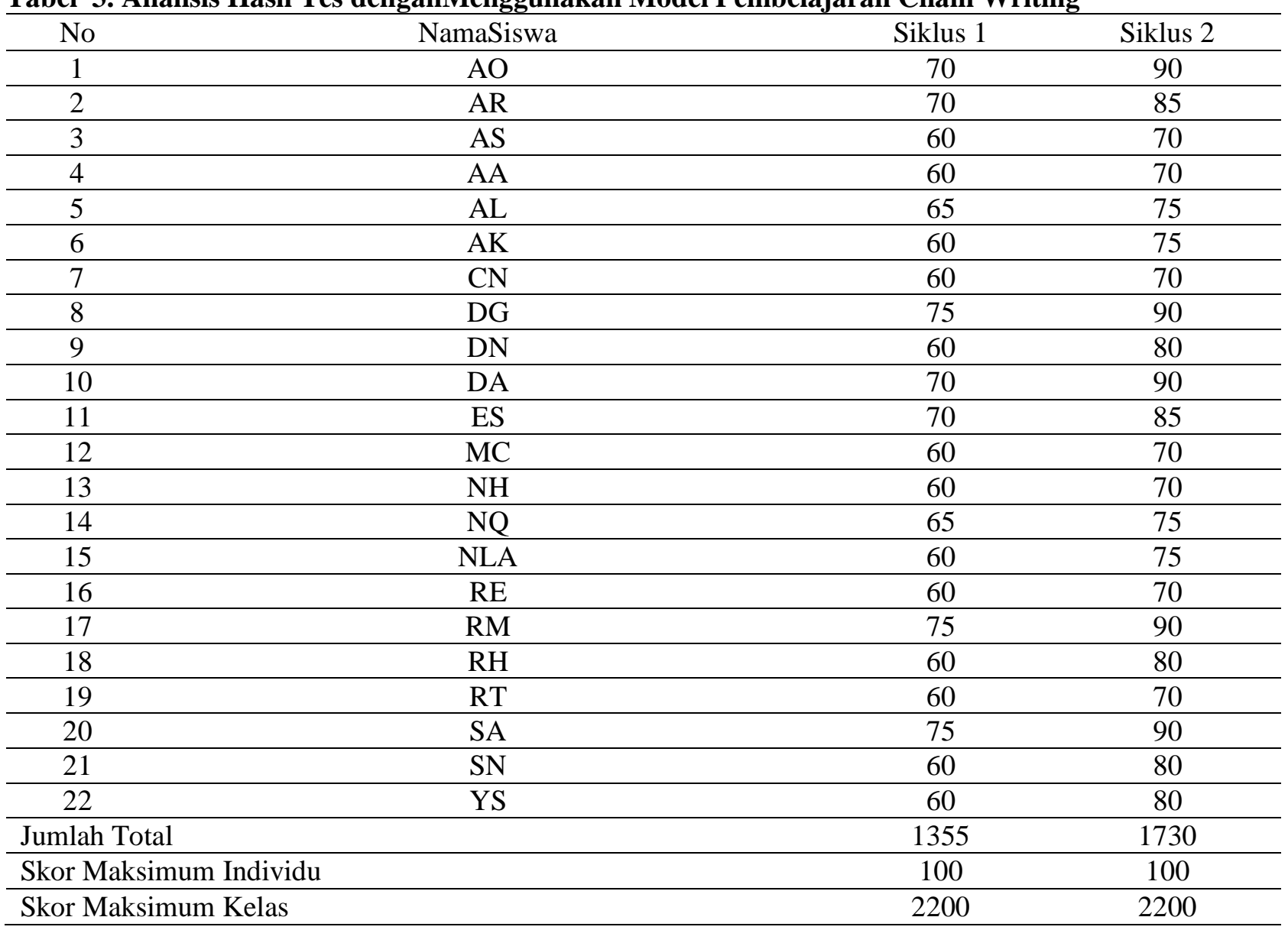

Analisis data dalam penelitian ini adalah sebagai berikut: (1) Pencapaian Prestasi Siswa melalui penerapan model pembelajaran chain writing teks sebelum diberi tindakan: $=1415 \times 100 \%=64,31 \%$; (2) Pencapaian peningkatan prestasi Siswa melalui model pembelajaran chain writing teks setelah diberi tindakan: $=1730 \times 100 \%=78,63 \%$
Berdasarkan pelaksanaan tindakan maka hasil observasi nilai, hasil dapat dikatakan sebagai berikut: a. Siklus pertama kegiatan belajar mengajar dengan model pembelajaran chain writing belum berhasil karena dalam pembelajaran masih terlihat Siswa yang bermain, bercerita, dan mengganggu Siswa lain. b. Model Pembelajaran dengan model 
pembelajaran chain writing dalam hal peningkatan kemampuan menulis teks prosedur belum tampak, sehingga hasil yang dicapai tidak maksimal (tuntas). c. Akan tetapi setelah dijelaskan, mereka bisa mengerti dan buktinya pada pertemuan kedua dan ketiga proses kegiatan belajar mengajar berjalan baik, semua siswa aktif dan lebih-lebih setelah ada rubrik penilaian proses, seluruh Siswa langsung aktif belajar.

\section{Pembahasan}

Berdasarkan hasil penelitian ini menunjukkan bahwa penerapan model pembelajaran chain witing memiliki dampak positif dalam meningkatkan kemampuan siswa dalam menulis teks prosedur. Hal ini dapat dilihat dari semakin mantapnya pemahaman siswa terhadap materi yang disampaikan guru (persentase ketuntasan belajar meningkat dari siklus 1, dan 2) yaitu; $64,31 \%$; $78,63 \%$.

Berdasarkan analisis data, diperoleh aktivitas Siswa dalam proses pembelajaran dengan model pembelajaran chain writing dalam setiap siklus mengalami peningkatan. Hal ini berdampak positif terhadap kemampuan menulis siswa yaitu dapat ditunjukkan dengan meningkatnya nilai rata-rata siswa pada setiap siklus yang terus mengalami peningkatan.

Berdasarkan hasil penelitian di atas, maka pembelajaransiswa untuk materi menulis teks prosedur melalui model pembelajaran chain writing hasilnya sangat baik. Hal itu tampak pada setiap pertemuan dari 22 orang Siswa pada saat penelitian ini dilakukan dengan nilai rata-rata mencapai $64,31 \% ; 78,63 \%$.

Dari analisis data di atas bahwa pembelajaran dengan model pembelajaran chain writing yang diterapkan pada pembelajaran Bahasa Inggris kelas IXA lebih berhasil dan dapat meningkatkan kemampuan siswa dalam menulis teks prosedur, oleh karena itu diharapkan kepada para guru SMP atau yang sederajat dapat melaksanakan pembelajaran dengan menggunakan model pembelajaran chain writing dalam mengajarkan menulis teks prosedur di kelas IX.

Berdasarkan Kurikulum Tahun 2013, Siswa dikatakan tuntas apabila Siswa telah mencapai nilai standar KKM 70. Sedangkan pada penelitian ini, pencapaian nilai 70 pada (siklus 2) telah tercapai sesuai target yang ditetapkan dalam Kurikulum 2013. Dengan demikian maka hipotesis yang diajukan dapat diterima.

\section{SIMPULAN DAN SARAN \\ Simpulan}

Akhirnya, peneliti dapat memperoleh beberapa hasil temuan setelah melaksanakan refleksi dan diskusi pada bab sebelumnya dan Penelitian Tindakan Kelas ini dapat disimpulkan sebagai berikut: (1). Penggunaan Model Pembelajaran Chain Writing dapat meningkatkan kemampuan siswa dalam menulis teks prosedur di kelas IX A SMP Negeri 5 Kubu. (2). Penggunaan Model Pembelajaran Chain Writing dapat meningkatkan hasil belajar siswa. Hal tersebut dapat dibuktikan dengan prosentase hasil belajar siswa pada siklus pertama sebesar $64,31 \%$ meningkat pada siklus kedua menjadi $78,63 \%$.

\section{Saran}

Proses pembelajaran yang baik dan menyenangkan adalah hal yang semestinya diciptakan oleh guru dalam membimbing dan memberi penguatan kepada siswa di kelas. Hal yang paling utama adalah: (1). Guru harus senantiasa melakukan pengamatan sejauh mana peningkatan belajar siswa di kelas. (2). Guru harus mulai mencoba menggunakan model pembelajaran seperti model pembelajaran chain writing dalam pembelajaran karena siswa dapat termotivasi dan bekerjasama melalui pembelajaran yang menyenangkan disesuaikan dengan konteks yang menjadi tujuan pembelajran. (3). Guru jugaharus mengembangkan model pembelajaran yang efektif, efisien dan menyenangkan yang dapat melibatkan siswa secara aktif dalam proses pembelajaran bahasa inggris untuk meningkatkan kompetensi menulis mereka.

\section{DAFTAR RUJUKAN}

Ali, Muhammad. 2000. Penelitian Pendidikan Prosedurdan Strategi. Bandung: Angkasa.

Arikunto, Suharsimi. 2005. Penelitian Tindakan Kelas. Jakarta: Dirjen PMPTK

Barnet, Sylvan.1979. A short Guide to Writting about Literature. Fourth edition. Boston Toronto:Little, Brown and Company.

Barnett \& Butler (1999). Atypical patterns of early attachment: Discussion and future direction. In J. I. Vondra and D Barnnet (Eds). Atypical attachment in infancy and early childhood among children at developmental risk (pp172192). Monographs of the Society for Research in Child Development, 64 (3, Serial No.258).

Bianco, A. 2002. One Minute Discipline: Classroom Management Strategies That Work. United State of America: John Wiley\&Sons, Inc.

Brown, H.D.1994. Principles of Language Learning and Teaching.New Jersey: PrenticeHall

Regents Englewood Clifft. San Fransisco State University.

Chandrasegaran, A.L., Treagust, D.F. \&Mocerino, M. (2007). "The development of a two - tier multiple choice diagnostic instrument for evaluating secondary school students' ability to describe and explain chemical reactions using multiple levels of representation". Chemistry Education Research and Practice,

Cohen, Andrew D. 1994. Assesing Language Ability in the Classroom. Second. Edition. Boston: Heinle\&Heinle Publishers.

Doff, Adrian (1999). Teaching English. Cambridge: Cambridge University Press.

Freeman-Larsen, Diana.1986. Techniques and Principles in Language Teaching.London: Oxford University press

Hedge, Tricia (2002). Teaching and Learning in the Language Classroom. Oxford: Oxford University Press.

Hornby, G. 2015. Inclusive Special Education: Development of a new theory for the education of children with special need and disabilities. British Journal of Special Education

Ida Nuraida. (2008).

ManajemenAdministrasiPerkantoran.Kanisius: Yogyakarta.

Ismail, Masya. 1994. "TeoriProsedur". Jakarta: Grasindo 
Kementerian Pendidikan dan Kebudayaan, (2013), Kurikulum 2013 dan Materi Sosialisasi kurikulum 2013.

Mackenzie, N., \&Veresov, N. 2013. How Drawing can Support Writing Acquisition: Text Costraction in Early Writing from a VygotskianPerpective. Australasian Journal of Early Childhood.
Marahimin, Ismail. (2001). Menulis secara populer.Jakarta : PT Dunia Pustaka Jaya

Silberman, Mel.1996. Active Learning. Diterjemahkan oleh H. Sardjuli, Dkk Massacusetts: A. Simon \& Schuster Company.

Ziv, D.N. (1984). The Effect off the Teacher Comments on the Writing of Four. College Freshmen. New York: The Guildford 